\section{NOTE ON THE}

USE OF SALICYLIC SILK AS A DRESSING FOR WOUNDS, WITH CASES.

BY J. LOCKHART GIBSON, M.B., C.M., RESIDENT PHYSICIAN, EDINBURGE ROYAL INFIRMARY; PRESIDENT OF THE ROYAL MEDICAL SOCIETY, EDINBURGH.

LAST winter I acted as Mr. Chiene's house-surgeon in the Edinburgh Royal Infirmary, and I have received his permission to publish the results we obtained under the use of salicylic silk between the deep and superficial layers of gauze in an antizeptic dressing. What led to the use of salicylic silk was the note of the results obtained in the Leeds Infirmary, published by Mr. Henry Brown in your number of Oct. 8th, 1881. Mr. Chiene did not, however, adopt the Leeds method in its entirety, but, as we think, improved upon it, and so brought out some of the chief advantages of the silk as an addition to an antiseptic gauze dressing.

Our method differed from that used at Leeds in this essential-viz, in the use of no mackintosh. Next the wound was placed a piece of protective of as small a size as possible, and often perforated, as it was used merely to prevent the dressing from sticking to the wound; then two or three layers of carbolic gauze wrung out of 1 to 40 carbolic lotion; above that a variable quatity of salicylic silk; and over all a large dressing of eight plies of carboic gauze. The large dressing we used to protect the silk, which was looked upun as an aseptic though not autiseptic reservoir, and therefore required an auti-eptic covering to prevent it from going wrong when moistened with discharge. It was not thought uecessary to soak the deep dressing in a stronger solution of carbolic acid than the usual 1 to 40 . The mackintosh was dispenved with because the use of the beautifully absorbent silk gave us the means of employing what Mr. Chiene had been long aiming at-viz, a dry dreasing. The advantages found in the silk were-dryness of our wounds, lessening of discharge, diminution of labour to the surgeon, and cheapness. The absence of the maclintosh allowed the fluid part of the discharge to evaporate, and the dressings, when removed, sometımes not till two or three weeks after their first application, were found to be acting the part of a huge scab and to be covering a healed wound. The discharge was lessened because the poulticing action due to the mackintosh was absent. Our wounds in almost every case were drained with chromic catgut, that dressing might not be necessitated for the removal of a drainage-tube. Horsehair stitches were employed, as being more rigid than catgut; as keeping the lips of a wound in more perfect coaptation, and as being easily removed after a wound is healed.

Cases Treated by Salucylic Silk in the Antiseptic Dressing.

\begin{tabular}{|c|c|c|c|}
\hline No. & Nature of case. & $\begin{array}{l}\text { No. of } \\
\text { dressings. }\end{array}$ & $\begin{array}{l}\text { Highest } \\
\text { temperature. }\end{array}$ \\
\hline 1 & Scirrhus of mamma and axillary & 1 & $992^{\circ}$ \\
\hline 2 & $\begin{array}{l}\text { glands. } \\
\text { Scrrrbus of mamma and axillary } \\
\text { glands. }\end{array}$ & 4 & $100 \cdot 8^{\circ}$ \\
\hline 3 & $\begin{array}{l}\text { Trephining for compound de- } \\
\text { pressed (punctured) fracture } \\
\text { of skull. }\end{array}$ & 1 & $99^{\circ}$ after 1st \\
\hline 4 & $\begin{array}{l}\text { Railway injury reflecting the } \\
\text { scalp from nearly the whole } \\
\text { of one side of the head, and } \\
\text { baring and scratching the bone } \\
\text { for an area of two inches in } \\
\text { diameter. }\end{array}$ & 1 & \\
\hline 5 & $\begin{array}{l}\text { Amputation through the middle } \\
\text { of thigh, for cario-necrosis. }\end{array}$ & 4 & $99^{\circ}$ \\
\hline 6 & $\begin{array}{l}\text { Five wounds of vertex, three } \\
\text { penetrating to the bone, and } \\
\text { one exposing a fissured frac- } \\
\text { ture. }\end{array}$ & 1 & $99^{\circ}$ \\
\hline$i$ & $\begin{array}{l}\text { Primary amputation below the } \\
\text { shoulder. }\end{array}$ & 5 & $99 \cdot 8^{\circ}$ \\
\hline 8 & $\begin{array}{l}\text { Syme's amputation at the ankle } \\
\text { (primary). }\end{array}$ & $\begin{array}{c}10 \\
(3 \text { for dis- } \\
\text { charge) }\end{array}$ & $100^{\circ}$ \\
\hline 9 & $\begin{array}{l}\text { Compound fracture of tibia and } \\
\text { fracture of fibula. }\end{array}$ & & $99^{\circ}$ \\
\hline 10 & Compound fracture of tibia. & 3 & $100^{\circ}$ \\
\hline 11 & $\begin{array}{l}\text { Compund fracture of tibia and } \\
\text { fibula, and compound disloca. } \\
\text { tion of the ankle. }\end{array}$ & 12 & $101^{\circ}$ \\
\hline 12 & $\begin{array}{l}\text { Primary amputation of middle } \\
\text { and index fingers, with por- } \\
\text { tions of their metacarpal bones. }\end{array}$ & 3 & $99^{\circ}$ \\
\hline
\end{tabular}

ON A CASE OF MALIGNANT CHOLERA. BY J. EDWIN COONEY, L.F.P.S.G., \&c.

MRS. C_- of Poplar, E., aged fifty-two, of spare habit, after three days of premonitory diarrhoea, during which period she dosed herself from a neighbouring draggist's to no effect, sent for me on June 21st, 1882. Arriving at 8 A.M. I found her shrieking and groaning, tortured by spasms of the carpo-pedal extremities, \&c., which were purple; the countenance had assumed the "facies choleritica," the eye being deeply sunken, red and injected, a broad and livid band encircling the lower part of the orbit; every feature was sharp and pinched, the complexion thick and muddy, and the lips and tongue purple. The whole body was bathed in a cold and clammy sweat; the voice scarcely audible. Temperature (external) was below $95^{\circ} \mathrm{F}$.; pulse not appre-
Dressed on the operating-table. Dressing removed on the fifteenth day. Wound found healed.

Only once dressed for discharge (oozing); twice for drainage-tube in axilla, which had been used because some glands surrounding the axillary vessols, and, therefore, not removed, had been touched with axillary vessels, and, therefore, not removed, had been touched with chloride of zinc. Drainage

Bone, to the size of a crown-piece, removed from vertex. Dressing Bone, to the size of a crown-piece, removed from vertex. Dressing
removed on the fifteenth day. Wound found healed. Dismissed a removed on the ifteenth

Dressed on the eleventh day, and found healed.

Healed on the seventeenth day. Dressed on the first, fourth, tenth, and seventeenth days.

Dressed on the twelfth day, and found healed.

Drainage-tube used because flaps were doubtful. Only two of the dressings were necessitated by discharge.

The frequent dressings were necessary for the watching of a linear slough of the beel-flap, which had been injured by the accident. The case was in for eight weeks. Very good stump.

Dressing removed in twenty-one days. Wound found to be quite superficial, with distinct union of bones. In another fortnight the wound healed, and patient was dismissed.

The patient (a woman) had fracture of the true pelvis and of a rib, in addition to the tibial injury. Dismissed in six weeks.

The cas to the tibial injary. Dise of the thix pelsis and of a rib, in the wound healed and a movable ankle. The last five dressings were not necessitated by discharge. Healed on the twelf th day. ciable in wrists and superficial arteries. Ooe of the heart's sounds only detected. Vomiting and purging incessant. She was passing painless motions of the true choleraic characterviz., copious white flocculi suspended in a watery fluid; urine was entirely suppressed since 4 A.M. She was, moreover, extremely restless and tossing about. In other words, she was in the algide state of malignant cholera. At 8 A.M. ice was given ad lib. to suck, also twenty grains of chloral hydrate, with twenty minims of dilute sulphuric acid in a little ice-water, which was rejected. This repeated at 8.30 A.M. was again vomited. At 9 A.M. I gave her a dose of chloral alone (twenty grains), which was retained; and up to 6 P.M. I gave ten grains of chloral every half-hour. Vomiting occurred occasionally in the intervals, but the drug was never rejected. At $10 \mathrm{~A}$.M. I found the bladder empty on passing a catheter, and resolved to inject a pint of tepid water in it to procure its absorution. The symptoms were still urgent, though the sweating and rest. lessness had ceased, and the cramps were shorter in dura. tion and further between. At noon, on passing the 